\title{
Results of U-Pb (LA-ICPMS) Dating of Detrital Zircons from Metaterrigenous Rocks of the Basement of the North Kara Basin
}

\author{
V. B. Ershova ${ }^{a}$, A. V. Prokopiev ${ }^{b}$, A. K. Khudoley ${ }^{a}$, G. V. Shneider ${ }^{c}$, T. Andersen ${ }^{d}$, K. Kullerud ${ }^{e}$, \\ A. A. Makar'ev ${ }^{f}$, Corresponding Member of the RAS A. V. Maslov ${ }^{g}$, and D. A. Kolchanov ${ }^{a}$ \\ Received March 2, 2015
}

\begin{abstract}
The U-Pb (LA-ICPMS) age was established for detrital zircons from the oldest, intensely deformed metasedimentary complexes without reliable fossils' record, which represent the folded basement of the North Kara basin and are exposed on Bol'shevik and Troinoi islands (Severnaya Zemlya and Izvestii TSIK archipelagoes, respectively). Our data suggest the common evolution of the Cambrian-Ordovician sequences exposed on the islands of both archipelagoes.
\end{abstract}

DOI: $10.1134 / \mathrm{S} 1028334 \mathrm{X} 15100013$

The North Kara basin, along with other basins of the Russian Arctic shelf, is a promising petroleum area, which is poorly studied because of its remoteness and the difficulty to access it. The basin spans the northern part of the Kara Sea, and its basement is exposed on the Severnaya Zemlya Archipelago and the North Taimyr. The basin is bounded by the continental margin of Eurasia from the north and by the Main Taimyr thrust, along which the rocks of the North Kara basement are thrust over the structures of an accretionary belt of Central Taimyr, from the south. The western and eastern boundaries of the basin are still a matter of debate (Fig. 1) [1, 2]. According to the concept of one of the authors, the studied region was an individual terrane in the Early to Middle Paleozoic $[3,4]$, whereas another considers it as a relatively large paleocontinent, e.g., Arctida [5] or Baltica [6].

\footnotetext{
${ }^{a}$ St. Petersburg State University, Universitetskaya nab. 7, St. Petersburg, 199034 Russia

${ }^{b}$ Diamond and Precious Metal Geology Institute, Siberian Branch, Russian Academy of Sciences, pr. Lenina 39, Yakutsk, 677007 Russia

${ }^{c}$ Karpinskii All-Russia Geological Research Institute, Srednii pr. 74, St. Petersburg, 199106 Russia

${ }^{d}$ University of Oslo, P.O. Box 1072 Blindern, Oslo, 0316 Norway

${ }^{e}$ University of Tromsø, Tromsø, 9037 Norway

${ }^{f}$ Polar Marine Geosurvey Expedition, ul. Pobedy 24, Lomonosov, St. Petersburg, 198412 Russia

${ }^{g}$ Zavaritsky Institute of Geology and Geochemistry, Ural Branch, Russian Academy of Sciences, Pochtovyi per. 7, Yekaterinburg, 620075 Russia

e-mail: ershovavictoria@gmail.com
}

In contrast to the westward Barents Sea basin, no wells have been drilled in the northern part of the Kara Sea. The geological structure of the basin is based on geophysical [1] and dredging data and studies of rock outcrops on the Severnaya Zemlya Archipelago, small islands of the Kara Sea, and the north of the Taimyr Peninsula [2, 7-9]. The age of the basement of the North Kara basin was previously considered Precambrian $[2,10]$. Recent dating of detrital zircons showed the Early Paleozoic age of the most deformed complexes [6-8].

The task of our study was to specify the age of the provenance areas of the most deformed metasedimentary complexes, which are the folded basement of the North Kara basin. To solve this task, we conducted the $\mathrm{U}-\mathrm{Pb}$ (LA-ICPMS) isotopic dating of detrital zircons extracted from the metasandstones of the Troinoi (Izvestii TSIK archipelago) and Bol'shevik (Severnaya Zemlya archipelago) islands.

The samples were preliminarily prepared, and the zircons were extracted at the Institute of Precambrian Geology and Geochronology following the standard technique. The zircons were dated at the University of Oslo (Norway) on a Nu Plasma HR multicollector mass spectrometer equipped with a NewWave Research LUV213 laser. The analytical error of U-Pb analyses is given at the $\pm 1 \sigma$ level. The age of crystallization of clastic zircons in the primary rocks was calculated from the ${ }^{207} \mathrm{~Pb} /{ }^{206} \mathrm{~Pb}$ and ${ }^{206} \mathrm{~Pb} /{ }^{238} \mathrm{U}$ ratios for zircons with an age of more and less than $1 \mathrm{Ga}$, respectively. The distribution of the probability density of ages was plotted in the Isoplot 4.0 program. The plots of the age distribution of the detrital zircons for the studied samples are shown in Fig. 2. The values of peaks that are formed by three or more dated grains are 


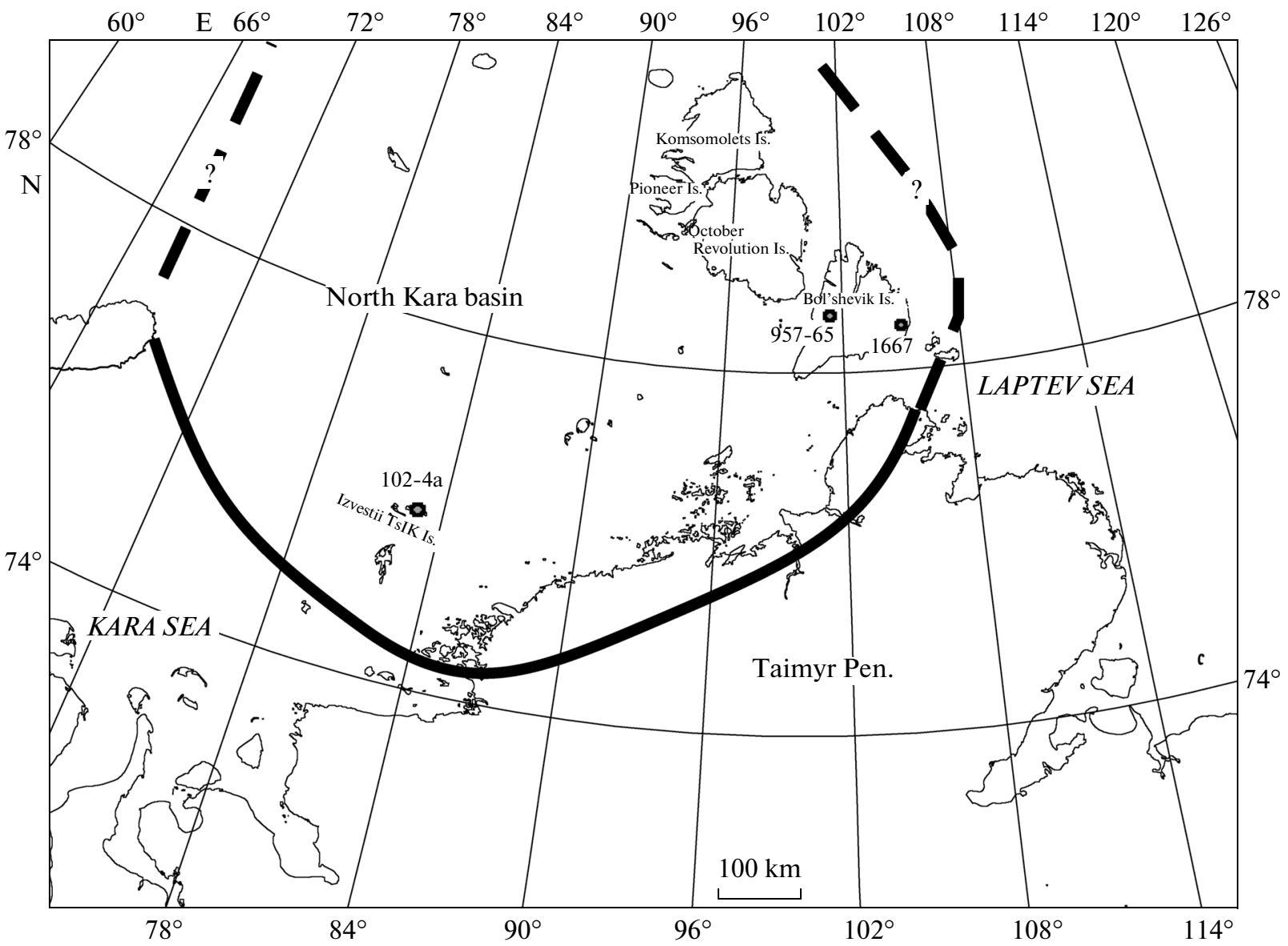

Fig. 1. Location of the North Kara basin and studied samples.

calculated in the Age Pick program elaborated at the University of Arizona (United States).

Overall, the distribution age spectra of the detrial zircons in samples are similar (Fig. 2). In sample 102-4a (Troinoi Island), 6, 11, and $70 \%$ of the detrital zircons are Paleoproterozoic, Mesoproterozoic, and Neoproterozoic, respectively, with superimposed peaks of $\sim 564$ and $549 \mathrm{Ma}$ and a small peak of $\sim 628 \mathrm{Ma}$. The Cambrian grains comprise $13 \%$ of the population (a peak of $\sim 534 \mathrm{Ma}$ ). According to [8], the age of the host rocks is Cambrian.

Sample 1667 (southeastern part of Bol'shevik Island) is dominated $(92 \%)$ by Precambrian zircons with a majority of Neoproterozoic grains similarly to sample 102-4a. The Paleoproterozoic ages $(6 \%)$ form a small peak of $\sim 1640$ Ma. The Mesoproterozoic grains compose $\sim 18 \%$ of the population with peaks of 1297 and $1097 \mathrm{Ma}$. The Neoproterozoic grains (68\%) are characterized by peaks of $\sim 701,661,619$, and $587 \mathrm{Ma}$. The Early Paleozoic age is typical of $8 \%$ of zircons (peaks of 538 and $485 \mathrm{Ma}$ ). The age of sampled rocks is Early to Middle Cambrian [8].

Sample 957-65 (western part of Bol'shevik Island) is also characterized by dominant Precambrian zir- cons $(87 \%)$. The Paleoproterozoic zircons comprise $8 \%$ without clear peaks. The Mesoproterozoic grains (17\%) form the peaks of $1558,1470,1226$, and $1167 \mathrm{Ma}$. Neoproterozoic grains (60\%) with peaks of 709, 690, 632, 606, 569, and $545 \mathrm{Ma}$ are dominant in the sample. The ages of the Early Paleozoic zircons (13\%) form a peak of $\sim 520 \mathrm{Ma}$. According to [8], the age of the country rocks is Middle Cambrian.

The ages of detrital zircons are broadly used to determine the maximum age of sedimentation, which is considered to be the age of the youngest grains. Often, this is the only way to determine the age of metamorphosed sedimentary rocks with poor fossils' record. For example, in sample 102-4a, the ages of the youngest grains with peaks of $\sim 534$ and 530 Ma point to sedimentation of these rocks occurred not earlier than the Early Cambrian and, generally, correspond rather well to the age recently determined for these rocks $[7,8]$. In sample 1667 , the youngest zircons with a peak of $485 \mathrm{Ma}$ indicate the formation of host rocks in the Late Cambrian-Early Ordovician. In sample 957-65, the Early Paleozoic peak is $520 \mathrm{Ma}$; however, two dated grains, taking into account the errors, are of Late Cambrian-Early Ordovician (466 \pm 12 and $502 \pm 7 \mathrm{Ma}$ ), which points to sedimentation of rocks 


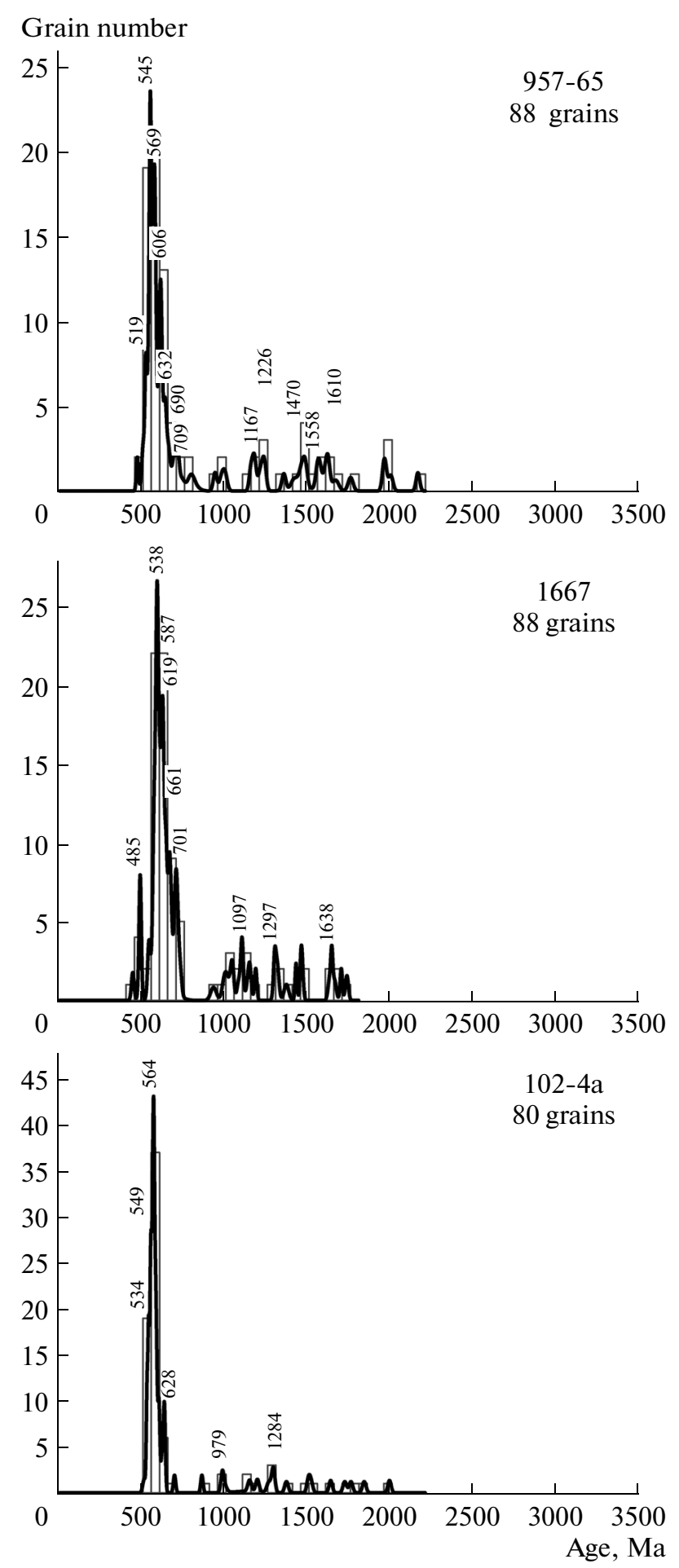

Fig. 2. Histograms and density curves of the probability of the age distribution of the detrital zircons from the studied samples. Numbers show the ages of peaks that are formed by no less than three grains.

at the Cambrian-Ordovician boundary. These new data indicate a broader occurrence of the Upper Cambrian-Lower Ordovician rocks on Bol'shevik Island than is shown on the newest geological maps [7].
The intensely deformed and metamorphosed Cambrian-Lower Ordovician sequences on Bol'shevik Island are overlapped with angular unconformity by Devonian and Carboniferous rocks [7]. On the northwestward October Revolution Island, the Lower Ordovician, relatively weakly deformed rocks lie with angular unconformity on deformed Cambrian rocks $[9,11]$. The presence of Cambrian and Latest Cambrian-Earliest Ordovician rocks on Bol'shevik Island with similar age distributions of detrital zircons with those from rocks of the same age of October Revolution Island [6], the similar orientation, and the style and intensity of deformations suggest a common evolution of the Cambrian-Ordovician rocks both islands. Our data on the ages of detrital zircons indicate the period of formation of the oldest sedimentary sequences of the Severnaya Zemlya and Izvestii TsIK archipelagoes. These sequences most likely compose the fold basement of the entire North Kara basin, and their age is Cambrian to the beginning of the Early Ordovician.

The age distribution of the detrital zircons in the studied samples is similar (Fig. 2): all the samples contain dominant Precambrian zircons with a majority of Neoproterozoic zircons, which probably indicates the contribution of the same clastic source to their formation. Paleoproterozoic grains are rare (weakly expressed peaks of $\sim 1640$ and $1610 \mathrm{Ma}$ in samples 1667 and 957-65, respectively). The Mesoproterozoic zircons in sample 102-4a comprise $10-11 \%$ without clear peaks, whereas their amount in samples 957-65 and 1667 reaches $18 \%$ (1300-1240 and 1165-1100 Ma). These peaks correlate with events that occurred in the Sveconorwegian (Grenville) fold belt [12]. The dominant Neoproterozoic detrital zircons with ages of 630-545 Ma indicate the abundance of Timanide complexes, which supplied the detrital zircons to the studied rocks [13-15].

Thus, the distribution age spectra of the detrital zircons from the deformed metasandstones of Bol'shevik and Troinoi islands (Severnaya Zemlya and Izvestii TsIK archipelagoes, respectively) indicate that the Timan margin of the Baltica paleocontinent was probably the major provenance area for the studied sequences and support the idea that the folded basement of the North Kara basin was part of the Baltica paleocontinent.

\section{ACKNOWLEDGMENTS}

This study was supported by the Russian Foundation for Basic Research (project nos. 13-05-00700 and 13-05-00943), St. Petersburg University (project no. 3.39.139.2014), Diamond and Precious Metal Geology Institute, Siberian Branch, Russian Academy of Sciences (Scientific Research Work no. VIII.66.1.4), the Presidium of the Russian Academy of Sciences (project no. 53), and Applied Scientific Research (project no. RFMEFI57614X0052). 


\section{REFERENCES}

1. N. A. Malyshev, V. A. Nikishin, A. M. Nikishin, V. V. Obmetko, V. N. Martirosyan, L. N. Kleshchina, Yu. V. Reydik, Dokl. Earth Sci. 445 (1), 791-795 (2012).

2. H. Lorenz, P. Mannik, D. Gee, and V. Proskurnin, Intern. J. Earth Sci. 97, 519-547 (2008).

3. N. A. Bogdanov and V. E. Khain, Explanatory Report to the Tectonic Map of Kara and Laptev Seas and North Siberia (Institut litosfery okrainnykh i vnutrennikh morei RAN, Moscow, 1998) [in Russian].

4. D. V. Metelkin, V. A. Vernikovsky, A. Yu. Kazansky, O. K. Bogolepova, A. P. Gubanov, Tectonophysics 398, 225-243 (2005).

5. L. P. Zonenshain, M. I. Kuz'min, and L. M. Natapov, Geology of the USSR: a Plate-Tectonic Synthesis (Geodynamics Ser. 21, Amer. Geophys. Union, Washington, 1990).

6. H. Lorenz, D. G. Gee, and A. Simonetti, Norw. J. Geol. 88 (4), 235-258 (2008).

7. State Geological Map of Russian Federation on a Scale of $1: 1000000$ (Third Generation). Sheet T-45-48. Cape Chelyuskin. Explanatory Report, Ed. by A. A. Makar'ev (Kartfabrika VSEGEI, St. Petersburg, 2013) [in Russian].
8. A. A. Makar'ev and E. M. Makar'eva, Razved. Okhr. Nedr, No. 8, 71-77 (2012) [in Russian].

9. H. Lorenz, D. G. Gee, and M. Whitehouse, Geol. Mag. 144, 105-125 (2007).

10. State Geological Map RF-200. Series Severozemel'skaya. Sheets T-47-VI, XI, XII; T-48-I, VII-X; T-47-XVIXVIII, XXII, XXIII; T-48-XIII-XVIII (Bol'shevik Islands). Explanatory Report, Ed. by V. A. Markovskii (MPR Rossii PGO Sevmorgeologiya, Moscow, 1999) [in Russian].

11. V. F. Proskurnin, Nedra Taimyra, is. 3, 68-76 (1999) [in Russian].

12. D. G. Gee, A. N. Larionov, L. Belyakova, and A. M. Pystin, in Proceeding of International Conference on Arctic Margins (ICAM) (Tromsø: Norw. Geol. Soc., 2007), pp. 75-76.

13. D. G. Gee, V. Pease, Geol. Soc. London Mem. 30 (2004), 1-3.

14. H. Lorenz, D. G. Gee, A. N. Larionov, and J. Majka, Geol. Mag. 149 (5), 875-891 (2012).

15. N. B. Kuznetsov, S. Yu. Orlov, E. L. Miller, A. A. Soboleva, O. V. Udoratina, in Proceedings of Conference on Current State of the Earth's Sciences (Mos. State Univ., Moscow, 2011), pp. 1017-1022 [in Russian].

Translated by I. Melekestseva 
Copyright of Doklady Earth Sciences is the property of Springer Science \& Business Media B.V. and its content may not be copied or emailed to multiple sites or posted to a listserv without the copyright holder's express written permission. However, users may print, download, or email articles for individual use. 